\title{
RELATION OF WORKER CHARACTERISTICS AND PERSONAL DUST LEVEL TO THE VITAL LUNG CAPACITY OF WORKERS IN THE FURNITURE INDUSTRY
}

\author{
Putri Arini \\ Depertment of Environmental Health, \\ Faculty of Public Health, Airlangga Univesity, Surabaya, Indonesia \\ Correspondence Address: Putri Arini \\ E-mail: putri.arini-2014@fkm.unair.ac.id
}

\begin{abstract}
Furniture industry is one of growing industry in Indonesia which has rapid growth. The process of its production brings one complex problem; wood dust. Workers who engage in the production process will have problem with their lung which can lead problem into their respiratory system. It is caused by the wood dust that mixed into oxygen they breath. Furthermore, if this condition happens in long period, it become a serious problem; impairment of vital pulmonary capacity. Besides, the impairment of vital pulmonary capacity can occur due to workers characteristics or conditions such as age, working history, working period, shelf period, illness history, smoking habit, diet, exercise, and the wearing of APD. The purpose of this research was to find out the relation between workers characteristics and personal dust level within vital capacity of lung. This research used cross sectional design with 17 respondents which was took by simple random sampling technique. This research took place at furniture industry X in Tubanan, Tandes, Surabaya, started from April to May 2018. Data was analysed using chi-square test and independent t-test with accuracy up to 95\%. Data was collected through interview, observation, and measurement. The result of this research showed that there was correlation between working period, shelf period, and smoking habit within vital pulmonary capacity. The conclusion of this research was that working period, shelf period, smoking habit had important role to workers vital pulmonary capacity in furniture industry.
\end{abstract}

Keywords: worker characteristics, wood dust, vital capacity of lung, furniture industry

\begin{abstract}
ABSTRAK
Industri mebel merupakan salah satu industri pengolahan kayu yang perkembangannya semakin pesat terutama di Indonesia. Proses kegiatan dalam pengolahan kayu menjadi produk jadi di industri mebel terdiri dari beberapa tahapan dimana proses tersebut menghasilkan bahan polutan yaitu debu kayu. Debu kayu yang terhirup oleh pekerja secara terus-menerus dapat berdampak buruk pada kesehatan pernapasannya. Dampak buruk yang sering terjadi adalah penurunan kapasitas vital paru. Selain disebabkan oleh paparan debu kayu, gangguan kapasitas vital paru dapat terjadi karena karakteristik atau kondisi pekerja seperti usia, riwayat pekerjaan, masa kerja, lama paparan, riwayat penyakit, kebiasaan merokok, status gizi, kebiasaan berolahraga, dan penggunaan APD. Tujuan dari penelitian ini adalah untuk mempelajari hubungan karakteristik pekerja dan kadar debu personal dengan kapasitas vital paru. Penelitian ini menggunakan rancangan cross sectional dengan jumlah sampel sebanyak 17 responden yang diambil menggunaka teknik simple random sampling. Lokasi penelitian berada di industri mebel X, Kelurahan Tubanan, Kecamatan Tandes Surabaya, mulai bulan April hingga Mei 2018. Data dianalisa menggunakan uji statistik chi-square dan t-test independent dengan tingkat kepercayaan 95\%. Data dikumpulkan dengan cara wawancara, observasi, dan pengukuran. Hasil penelitian menunjukkan ada hubungan masa kerja, lama paparan, dan kebiasaan merokok dengan kapasitas vital paru. Kesimpulan dari penelitian ini adalah bahwa masa kerja, lama paparan, dan kebiasaan merokok memiliki peran penting terhadap kapasitas vital paru pekerja di industri mebel.
\end{abstract}

Kata kunci: karakteristik pekerja, debu kayu, kapasitas vital paru, industri mebel

\section{INTRODUCTION}

In today's modern era of industry development is assessed rapidly especially in Indonesia. One type of industry that is developing is the wood processing industry or furniture. It can be seen from the use of forest results up to 33. Million $\mathrm{m}^{\wedge} 3$ per year (Permatasari, L. O., 2017). But the furniture industry has a bad impact on the 
environment as the industry is producing the byproduct of wood dust. The resulting wood dust can pollute the environment and adversely affect the health of workers.

WHO Data in 2010 estimateabout 2. million people around the world experience exposure by wood dust as they work. The highest exposure intensity in the furniture industry is on the sanding area (Irjayanti, A., 2012).

Workers who accidentally breathe wood dust can suffer from work diseases such as complaints on the respiratory system. This can reduce the function or lung capacity of the worker. Pneumokoniosis is one of the lung abnormalities caused by dust that is buried in the lungs with symptoms of cough, shortness of breath, and severe chest (Departemen Kesehatan RI., 2003). Impaired lung vital capacity is divided into obstruction and retricction (Suma'mur., 2009).

The small number of health impacts given due to the exposure of wood dust depends on the resulting dust level factor, long exposure, working period, worker condition, and environmental conditions (Mirza, 2010). Worker conditions such as gender, age, BMI, exercising, smoking, job history, disease history, and application of APD are factors supporting the occurrence of respiratory distress due to dust (Budiono, 2007).

The results of the research (Amelia, N. G.S., Oksfriani, J.S., 2016) on the Vital capacity of lung furniture workers in Kampung Islam Manado village states that from 40 respondents there are $70 \%$ of workers have abnormal pulmonary capacity, and $90 \%$ of workers have long exposure $>8$ hours/ Day. There is a connection to the use of APD with a vital pulmonary capacity $(\mathrm{P}=0,012)$ and there is no connection between prolonged exposure and the vital pulmonary capacity $(\mathrm{P}=$ 0,073).

Another study conducted (Permatasari, L. O., 2017) about the relationship between Total dust content and
Personal Hygiene with impaired lung function in wood processing workers in CV Indo Jati Utama Semarang, that there is a relationship of the level of inhalation dust, Total dust content, and Use of PPE with impaired wood processing workers ' lung function.

$X$ furniture Industry in Tubanan village, Surabaya is a type of informal industry that is individually managed and has stood for more than 15 years, this furniture industry manages plywood type. The number of employees was 20 workers with details of 18 people in production, 1 person as a driver, and 1 person as a secretary. Production unit are divided into carpenters and finishing parts.

Preliminary review results in furniture industry $\mathrm{X}$ is obtained that the working environment is filled with wood dust good dust that accumulate. On the floor or dust floating in the air. Environments with such conditions may bring adverse impacts to respiratory health, workers. Most workers do not want to wear masks while working, but some are always wearing masks. Smoking became a habit by all workers in the furniture industry $\mathrm{X}$. The respiratory health complaints often experienced by workers based on the results of preliminary interviews i.e. shortness of breath, cough, sneezing, and red eyes.

The purpose of this research is to study the relationship characteristic of workers and personal dust levels with a vital lung capacity in the furniture industry $\mathrm{X}$, village Tubanan, Surabaya.

\section{METHODS}

This research includes observational research with analytical approaches. Cross sectional method as it takes free and bonded variable data at the same time. The research location is in the furniture industry $\mathrm{X}$ in Tubanan Village, Tandes subdistrict, Surabaya, the research time is conducted in April - May 2018. The research population is a total of 18 employees. Furthermore, samples of 
research that meet the inclusion criteria that have a working period of $>1$ year, workers are active and passive smokers, from the calculation of samples using the formula Lemeshow obtained as many as 17 respondents.

Dependent variables of this research are the vital capacity of the lungs of workers and independent variables (free) namely personal dust levels (respirable), age, length of exposure, length of work, work history, history of the disease, nutritional status, smoking habits, Exercise habits and use of APD masks.

Measurements of personal dust levels using the Personal Dust Sampler tool with the NAB based on the estimated number 13 year 2011, measuring the vital lung capacity using spirometer, determination of nutritional status based on height and weight calculation The body using the benchmark is a practical guideline for adult nutritional Status monitoring. By the (Departemen Kesehatan RI., 2003), and other characteristics of respondents were known through interviews by researchers using the questionnaire.

This research uses the data analysis of univariate and bivariate. The purpose of univariate analysis is to provide an overview of distribution, frequency of each variable. Meanwhile, sufficient analysis aims to connect two variables (free and bound variables) that are expected to have a relationship with use, the Chi-square test and the T-Test independent with a degree of confidence of $95 \%(\alpha=0.05)$. This research has obtained a description of the passing of the Ethics Commission FKM No: 181KEPK.

\section{RESULT}

The results on 17 respondents in the furniture industry $\mathrm{X}$ of Tubanan Village, Tandes subdistrict, Surabaya, showed the distribution of the characteristics of workers and the personal wood dust levels are as follows.
Based on Table 1 it is known that most of the $\mathrm{X}$ furniture industry workers in the village Tubanan District Tandes Surabaya has an age of $>40$ years, which is as much as 11 respondents $(65 \%)$. The youngest working age is 23 years old and the oldest age is 61 years.

Age

Table 1. Age frequency distribution in Xfurniture industry workers of the village in Tubanan year 2018

\begin{tabular}{ccc}
\hline Age & $\mathrm{n}$ & $\%$ \\
\hline 20-30 year & 5 & 29 \\
\hline 31-40 year & 1 & 6 \\
\hline \$40 year & 11 & 65 \\
\hline Total & 17 & 100 \\
\hline
\end{tabular}

\section{Employment Period}

Table 2. Frequency distribution of working time on furniture industrial worker $\mathrm{X}$ in village Tubanan year 2018

\begin{tabular}{lccc}
\hline \multicolumn{1}{c}{ Variabel } & Mean & SD & $\begin{array}{c}\text { Min- } \\
\text { Max }\end{array}$ \\
\hline $\begin{array}{l}\text { Employment } \\
\text { Period }\end{array}$ & 10,88 & 5,16 & $5-20$ \\
\hline
\end{tabular}

Based on Table 2 It is known that the average working period of workers in the furniture industry $\mathrm{X}$ is 10.88 years old with a standard deviation of 5.16. The youngest working period the workers have is 5 years and the oldest working period is 20 years.

\section{Prolonged exposure}

Table 3. Long frequency distribution of exposure to industrial workers of furniture $\mathrm{X}$ The village Tubanan year 2018

\begin{tabular}{lccc}
\hline Variabel & Mean & SD & $\begin{array}{l}\text { Min- } \\
\text { Max }\end{array}$ \\
\hline $\begin{array}{l}\text { Prolonged } \\
\text { exposure }\end{array}$ & 8,00 & 1,06 & $6-9$ \\
\hline
\end{tabular}

According to Table 3 it is known that the average long exposure of workers 
to wood dust is 8.00 hours/day with a standard deviation of 1.06 . The minimum exposure is 6 hours/day, while the oldest exposure is 9 hours/day and the length of the exposure has exceeded the specified NAB limit.

\section{Respiratory tract disease History}

Table 4. Frequency distribution of respiratory tract diseases in $\mathrm{X}$ furniture industry worker in Tubanan village year 2018

\begin{tabular}{lrr}
\hline Disease history & $\mathbf{n}$ & \% \\
\hline Never & 14 & 82 \\
\hline Ever & 3 & 18 \\
\hline \multicolumn{1}{c}{ Total } & 17 & 100 \\
\hline
\end{tabular}

According to Table 4 it is known that most workers in the furniture industry $\mathrm{X}$ have never suffered a respiratory tract disease that is as much as 14 respondents $(82 \%)$. Workers who claim to have fewer respiratory tract disease history of 3 people $(18 \%$

\section{Habit of smoking}

According to Table 5 it is known that the habit of smoking on workers in the furniture industry $X$ more in the heavy smoker group as much as 9 respondents (53\%) Compared to 3 respondents (18\%) of light smokers.

Table 5. Frequency distribution of smoking habits in the $\mathrm{X}$ furniture industry worker of the village Tubanan year 2018

\begin{tabular}{lrr}
\hline Habit of smoking & n & \% \\
\hline Light Smoker & 3 & 18 \\
\hline Moderate Smoker & 5 & 29 \\
\hline Heavy Smoker & 9 & 53 \\
\hline \multicolumn{1}{c}{ Total } & 17 & 100 \\
\hline
\end{tabular}

\section{Nutritional Status}

Based on Table 6, it is known that workers in the furniture industry $\mathrm{X}$ normal nutrient status are as much as 11 respondents $(65 \%)$. The number is larger than that of lean and obese nutritional status workers

Table 6. Distribution of nutrient Status in the industrial worker of furniture $\mathrm{X}$ of the village Tubanan year 2018

\begin{tabular}{lrr}
\hline \multicolumn{1}{c}{ Status Gizi } & n & \% \\
\hline Skinny & 5 & 29 \\
\hline Normal & 11 & 65 \\
\hline Fat $\quad 1$ & 6 \\
\hline \multicolumn{1}{c}{ Total } & 17 & 100 \\
\hline
\end{tabular}

\section{Sports Habits}

Table 7. Frequency distribution of sports habits in the $\mathrm{X}$ furniture industry worker in Tubanan village year 2018

\begin{tabular}{crc}
\hline $\begin{array}{c}\text { Kebiasaan } \\
\text { Olahraga }\end{array}$ & n & \% \\
\hline Not doing & 8 & 47 \\
\hline Always do & 9 & 53 \\
\hline Total & 17 & 100 \\
\hline
\end{tabular}

Based on Table 7 known that workers in the furniture industry $\mathrm{X}$ aware of the importance of exercise, visible from the results as many as 9 respondents (53\%) Who always do sports even though who do not exercise also a lot of 8 respondents $(47 \%)$.

\section{Use of PPE Masks}

Tabel 8. Frequency distribution of PPE masks on industrial Workers of furniture $\mathrm{X}$ in the village Tubanan year 2018

\begin{tabular}{lrr}
\hline $\begin{array}{c}\text { Penggunaan } \\
\text { APD }\end{array}$ & n & \% \\
\hline Never & 8 & 47 \\
\hline Rarely & 6 & 35 \\
\hline Always & 3 & 18 \\
\hline \multicolumn{1}{c}{ Total } & 17 & 100 \\
\hline
\end{tabular}

Based on Table 8 , it is known that workers in the $\mathrm{X}$ furniture industry at the time of work never wear personal protective equipment (APD) in the form of 
masks as much as 8 respondents $(47 \%)$ The number is more than the worker who always wears 3 people (18\%).

\section{Personal Dust Levels}

Based on Table 9 it is known that the individual dust content received by the furniture industry worker X More exposure is $\leq 3 \mathrm{mg} / \mathrm{m}^{\wedge} 3$ which is 10 respondents $(59 \%)$.

Table 9. Frequency distribution 2018 of Personal dust on furniture industry worker $\mathrm{X}$

\begin{tabular}{ccc}
\hline Dust Levels & n & \% \\
\hline$\leq 3 \mathrm{mg} / \mathrm{m}^{3}$ & 10 & 59 \\
\hline$>3 \mathrm{mg} / \mathrm{m}^{3}$ & 7 & 41 \\
\hline Total & 17 & 100 \\
\hline
\end{tabular}

\section{Vital Lung capacity}

Table 10. Frequency distribution of Vital lung capacity in industrial workers of furniture $\mathrm{X}$ in the village Tubanan year 2018

\begin{tabular}{lrr}
\hline $\begin{array}{c}\text { Kapasitas } \\
\text { Vital Paru }\end{array}$ & n & \% \\
\hline Normal & 5 & 29 \\
\hline Upnormal & 12 & 71 \\
\hline \multicolumn{1}{c}{ Total } & 17 & 100 \\
\hline
\end{tabular}

Based on Table 10 it is known that workers in the $\mathrm{X}$ furniture industry with a vital pulmonary capacity of 12 respondents (71\%) More than workers with normal pulmonary capacity $(29 \%)$. In the $X$ furniture industry worker who suffered from restrictive pulmonary function as much as 7 workers, while obstructive pulmonary function disorder as many as 5 workers.

\section{Working age relationship with Vital lung capacity}

Age is one of the important variables that can affect the condition of the individual lung function. $\mathrm{X}$ Furniture industry worker in the village of Tubanan mostly aged $>40$ years. The results of the cross tabulation showed that workers who experienced substantial pulmonary capacity disorders also occurred, at the age of $>40$ years, namely 8 respondents. The results of the chi-square statistical test obtained the value $\mathrm{P}=0,701>0.05$, indicating that there is no age relationship with the vital lung capacity.

\section{The relationship with lung Vital capacity}

The work period of workers in the furniture industry $\mathrm{X}$ until the time of the study is calculated in oneyear. The results of the cross tabulation showed that, workers who experience a lot of lung vital capacity occurs in workers who already have a working period of 12.67 years that is 12 respondents. The results of the statistical TTest independent obtained the value $\mathrm{P}=$ $0,021>0.05$, indicating that there is a working period relationship with the vital lung capacity.

\section{Long relationship with Vital lung capacity}

Prolonged exposure is the time workers are exposed by wood dust in a matter of days/hours. Results of the cross tabulation showed that, workers in the $\mathrm{X}$ furniture industry experienced a lot of pulmonary capacity disorders occur in workers who have long exposure 8.50 hours/day is 12 respondents. Statistical results of T-Test independent obtained the value $\mathrm{P}=0,000>0.05$, indicating that there is an old connection with the vital lung capacity.

\section{The relationship of respiratory tract disease history with Vital lung capacity}

The history of respiratory tract disease is a history of illness ever suffered. Previous worker or congenital illness/from birth. The results of the cross tabulation showed that workers in the $\mathrm{X}$ furniture industry experienced a lot of pulmonary capacity disorders occurring in the workers who do not have a history of the disease 9 workers respiratory tract. The results of the 
chi-square statistical test obtained the value $\mathrm{P}=0,593<0.05$, indicating that there is no history of disease with a vital lung capacity.

\section{The relationship of smoking habits with a Vital lung capacity}

Smoking habit is a recurrent cigarette smoking activity. Ranging from 1 bar, or more in one day. The results of tabulation, cross indicates that the habit of smoking workers in the furniture industry $\mathrm{X}$ most experiencing the disturbance of the vital lung capacity is the weight category as much as 7 workers. The results of the chisquare statistical test obtained the value $\mathrm{P}=$ $0,012>0.05$, indicating that there is a relationship of smoking habit with a vital lung capacity.

\section{Relationship of nutritional Status with Vital lung capacity}

Nutritional Status is an overview of the nutritional condition of adults with calculations. Body mass Index (BMI). Results of cross-tabulation, indicating that workers in the furniture industry $\mathrm{X}$ that many experience impaired lung vital capacity namely status. Normal nutrition as much as 8 workers compared to the skinny and obese. The results of the chi-square statistical test obtained the value $\mathrm{P}=0,701$ $<0.05$, indicating that there is no nutritional status relationship with the vital lung capacity.

\section{Exercise habits with a Vital lung capacity}

Exercise habits are sporting activities carried out by workers at least 3 times a week. Results of cross-tabulation, indicating that workers in the $\mathrm{X}$ furniture industry are experiencing many of the vital lung capacity disorders are those who have exercise habits of as many as 7 workers. The results of the chi-square statistical test get a value of $\mathrm{P}=0,875<0.05$, indicating that there is no exercise habit with the vital lung capacity.

\section{The relationship of APD masks with a Vital lung capacity}

Use of personal protective equipment (APD). The mask by the worker aims to reduce exposure to dust while working. Cross tabulation results indicate that. Workers in the $\mathrm{X}$ furniture industry most experienced a vital pulmonary capacity disorder is that never wear APD masks when working 5 workers. The results of the chi-square statistical test obtained the value $\mathrm{P}=0,465<0.05$, indicating that there is no connection of the APD mask with a vital lung capacity.

\section{Personal Dust level relations with Vital lung capacity}

Personal dust levels are the result of personal dust measurements on workers. Use a Personal dust sampler tool. Results. Cross tabulation indicates that the dust level $\leq 3 \mathrm{mg} / \mathrm{m}^{\wedge} 3$ or $>3 \mathrm{mg} / \mathrm{m}^{\wedge} 3$, which is experiencing a significant amount of lung vital capacity of each 6 workers. Results of the chi-square statistical test obtained the value $\mathrm{P}=0,546<0.05$, indicating that there is no relationship of individual dust levels with a vital lung capacity.

\section{Pearson Correlation Test}

After the analysis of the bivariate, free variables that have a significant connection with the variables are tied between the old exposure, the working period, and the habit of smoking. These three free variables are then conducted Pearson correlation test to look at the direction of the relationship and determine the weak weakness of the relationship between free and bonded variables.

The result of the value of the correlation coefficient (r) on the old variable of exposure is 0.753 indicating that the relationship between prolonged exposure to the vital caasitas is strong/high. In the working period variable, the value of the correlation coefficient of 0.552 indicates that the relationship is quite strong, as well as the variable smoking habit has a 
correlation coefficient value of 0.598 which indicates the relationship is quite strong. The direction of the relationship of the three free variables above is indicating a negative direction (-). That the longer the working period and long exposure to dust workers experienced by the industry, the worsening conditions of their vital lung capacity, as well as the longer the habit of smoking by workers, it will be heavy the condition of its function.

\section{DISCUSSION}

Working process in furniture industry X, Tubanan Village starts from measurement of wood, then cut wood using cutting machine and assembled. Furthermore, the wood is sanded so that the surface is flat and smooth, then the process of giving the drug so that the wood can last longer and as a base before painting. The next stage of painting and giving varnish on wood. The final stage is to assemble the wood that has been formed such as a readymade goods.

Workers in the furniture industry have a risk to the exposure of wood dust resulting from the cutting and sanding of wood. The results of the measurement of lung vital capacity of 17 workers in the X furniture industry, the village of Tubanan was obtained by 12 respondents had a KVP disorder.

\section{Age relationship with Vital lung capacity}

The chi-square test results in relation to age with a vital lung capacity on workers in the $\mathrm{X}$ furniture industry, indicating that there is no relationship. This result is backed by the study of (Pradesi, R, 2018) stating that there is no age relationship with the vital lung capacity in the workers ' production department of PT. $\mathrm{X}(p=0,575)$, it is known that workers with KVP condition are not normal much occurs at the age of $<40$ Years. In line with the research of (Rasyid, 2013) that there is no age relationship with KVP on the workers of printing industry Mega Mall Ciputat ( $p=$ 0,948).

In theory, the age of man can affect the frequency and respiratory capacity, increase in lung capacity as the age increases, pulmonary function continues to increase at the age of 22-30 years after it decreased when someone reached 40 years old. The number of furniture industry workers $\mathrm{X}>40$ years or enter the elderly as much as 11 respondents, the remaining 6 respondents entered the young age of 20-40 years. So there is still the potential that worker life affects the respiratory system.

In this research, there is another variable influence with the occurrence of KVP disorder that is total dust content. Environmental conditions that are full of dust with long periods of time and long exposure can have a bad impact on worker health. In addition, workers who smoke can increase the incidence of KVP disorder. Based on (Suryono, 2001) that cigarette smoke leads to pulmonary irritation and is carried away in the bloodstream, smoking habits are the biggest cause of KVP decline compared to hazards in the working environment.

\section{The relationship with lung Vital capacity}

The chi-square test results of a working relationship with the vital lung capacity of the worker in the $\mathrm{X}$ furniture industry, indicating there is a significant relationship $(P=0,021)$. The result is the same with the research (Isnaini, A., Setyoko, 2015) stating there is a relationship between the working period with lung function in antique furniture worker Lho in Jepara $(P=0,000)$. Likewise, the research that there is a working relationship with KVP on rice milling workers in the white stone division at PT. Sinar Utama Karya $(p=0,021)$.

According to the Theory of (Khumaidah, 2009) that the length of a person's working life in a dusty workplace will increase the potential occurrence of pulmonary faal disorder. The working period has a positive and negative impact, 
the positive impact if the longer the individual's employment will provide a lot of experience in working. Negative impact if the longer the individual's employment will trigger a working health disorder due to exposure to hazards in the work environment

Type of informal industry such as the $\mathrm{X}$ furniture industry, will be found many workers who have been working for more than 10 years. Work activity conducted for approximately 10 years has a negative impact on the health of lung function of workers due to exposure to wood dust in the environment.

\section{Long relationship with Vital lung capacity}

The chi-square test results of a working relationship with the vital lung capacity of the pekrja in the $\mathrm{X}$ furniture industry, indicating there is a significant relationship $(P=0,000)$. These results are aligned with the son's research (2014) that there is a relationship between the old work with the vital capacity of the lungs welding workshop worker in Cirendeu village $(P=$ $0,012)$.

In the results of this research workers who experience impaired have long exposure more than 8 hours/day. This is in line with the theory of (Suma'mur., 2009) stating that more and more prolonged exposure will increase the potential of lung dysfunction in workers.

One of the factors that affect pulmonary dysfunction is prolonged exposure. But the health problems made can not occur in a day took a long time. According to (Soeripto, 2008) Occurrence of pulmonary function disorder is a chronic deforming effect so that the impact can be seen over a long period of time.

\section{The relationship of respiratory tract disease history with Vital lung capacity}

Chi-Square test results on the relationship of respiratory tract disease history with a vital lung capacity in the worker in the $\mathrm{X}$ furniture industry, indicating no relation $(P=0,593)$. This results in line with the research of (Oviera, A., Siswi Jayanti, 2016) that there is no history of disease with KVP in wood processing industry workers at PT. X Jepara $(p=0,974)$.

Diseases such as

TUBERCULOSIS, asthma, emphysema, and lung cancer decrease a person's vital lung capacity. Basically respiratory or lung disease that a person has suffered tends to reduce perfusion ventilation so that the exchange of air in the alveoli will be reduced and lowering the oxygen level in the blood (Budiono, 2007). Interviews say that complaints suffered by workers are only cough, flu, and shortness of breath, there is no history of the heavy illness that they experience in the respiratory tract area.

\section{The relationship of smoking habits with a Vital lung capacity}

Chi-Square test results on the relationship of smoking habits to the vital lung capacity of workers in the X furniture industry, indicating there is a relationship $(P=0,012)$. The result is the same with research (Nurkhaleda, B., 2016) that there is a habit of smoking a relationship with the capacity of lung function on welding workers in PT. X Kota Semarang ( $p=$ $0.001)$.

According to (Sukawati, E dan Setiani, 2014) smoking habits may trigger the occurrence of subjective complaints of the respiratory tract. Cigarette smoke results in the secretion of lenders that cripple cilia and result in airway inhibition. Ancient research (2013) expressed the habit of smoking is a supporting factor from impaired obstructive pulmonary function is not a restrictive contributing factor. So that workers who are exposed to dust in the workplace and smoking will accelerate the decrease in lung function.

All workers in the $\mathrm{X}$ furniture industry have a habit of smoking. The results of interviews with workers said that they could spend cigarettes 1 to 2 packs in 
a day. When working the workers also smoke, because there is no banned smoking in the work environment.

\section{Relationship of nutritional Status with Vital lung capacity}

Chi-Square test results on the relationship of nutritional status to the vital lung capacity of workers in the $\mathrm{X}$ furniture industry, indicating no relation $(P=0,701)$. This result is similar to the research of (Permatasari, L. O., 2017) stating that there is no relationship of nutritional status with impaired lung function in wood processing workers in CV Indo Jati Utama Semarang $(p=0,128)$.

The theory explains that nutritional deficiencies are continuously causing the physiological disorders that may be able to lower KVP (Departemen Kesehatan RI., 2003). Individuals with obese nutritional status make the pulmonary wall disturbed so as to affect pulmonary ventilation and result in decreased pulmonary function.

The results of this study were unrelated due to workers with normal nutritional status experienced KVP disorders more than with workers with lean or obese nutritional status. It is not only influenced by the nutritional status alone, but there are other factors that are influential such as smoking habit. A person whose nutritional status is normal but smoking will accelerate pulmonary function decline.

\section{Exercise habits with a Vital lung capacity}

Chi-Square test results on the habit of exercising habits with a vital lung capacity on workers in the $\mathrm{X}$ furniture industry, indicating no relation $(P=0,875)$. In line with (Simanjuntak, N.S.R., Ari, S., Ida, 2013) that there is no habit of exercising with impaired lung function on workers at the location of coal yard PLTU X Jepara $(p=0,894)$.

The above results are not in line with the theory that Oalahraga with KVP is closely related because someone with KVP good condition in exercising is not easy to feel tired. Conversely if many individual lung conditions contain pollutant substances can reduce lung work thereby lowering KVP (Yuwono, 2005). Good sports are done during young age to elderly. Exercise can be carried out gradually from warming up to 5-10 minutes then core exercises at least 20 minutes, and terminated cooling for 5-10 minutes. The frequency of exercise is 3-5 times a week and is done regularly (Karim, 2006).

\section{The relationship of APD masks with a Vital lung capacity}

Chi-Square test results on the relationship of use of APD masks with a vital lung capacity on workers in the $\mathrm{X}$ furniture industry, indicating no relation $(P$ $=0,462)$. The results are in line with the research of (Oviera, A., Siswi Jayanti, 2016) that there is no connection of the use of masks to the vital lung capacity in the workers of wood processing industry at PT. X Jepara $(p=0,097)$.

According to (Purba, 2013) the longer. The worker is exposed to dust and does not use the APD will, enlarging the risk of pulmonary function disorders. Using an APD mask helps to reduce exposure to the worker's inhalation in the workplace.

In the furniture industry $\mathrm{X}$, workers who do not wear masks are more than those wearing. Reason. Workers do not want to wear masks while working is uncomfortable and difficulty breathing. While the worker who always wears a mask using a type of mask made of cloth that is usually used when driving a motorcycle instead of a special mask as a dust filter, the cloth mask is washed 2 times in week.

\section{Connection of individual dust levels with Vital lung capacity}

Chi-Square test results on the relationship of individual dust levels with a vital lung capacity on workers in the $\mathrm{X}$ furniture industry, indicating no association $(p=0,546)$. Unlike the research of (Anes, 
N, I., Kawatu PAT, 2015) which states there is a link between the personal dust level and the impaired pulmonary function of pekrja in the cement bagging unit PT. Tonasa Line Bitung $(p=0,023)$.

(Ma'rufi, 2016) states that wood dust causes restriction of pulmonary function of lung stiffness, thereby limiting lung development. The process of restriction is the interaction between the dust that is inhalation of the lung cells, the dust will go into alveoli and further dipagocytosis by macrophages. Toxiccontaining dust of macrophages stimulates the formation of new macrophages. Toxic dust will be diplocytosis by the new macrophages so that the autolysides occur, and the occurrence repeatedly progresses. Due to fibrosis, the lungs will experience stiffness and experience a restrictive pulmonary development disorder (Simanjuntak, N.S.R., Ari, S., Ida, 2013). Wood dust itself contains lignin and cellulose, as well as fungi, parasite, and chemicals used in wood/furniture industry that is capable of triggering allergic or inflammatory reactions (Algranti et al, 2005).

\section{CONCLUSION}

Incan be concluded that there is a correlation between the working period, the length of exposure, and the habit of smoking in the furniture industry $\mathrm{X}$, village Tubanan Surabaya. There is no relationship between age, respiratory tract disease history, nutritional status, exercise habits, use of APD masks, and dust levels.

Test coefficient of correlation on all three free variables that have a significant relationship with a bound variable, indicating that the free variable that has the most powerful relationship is the long exposure $(r=0,753)$. The direction of the relationship of the three free variables indicates a negative direction, that the longer the length of work and the length of exposure of wood that workers experienced, it will exacerbate the condition of their vital lung capacity, as well as the longer the smoking habit Workers will also exacerbate the vital capacity of workers.

It is recommended for workers to leave smoking habit. and apply a healthy lifestyle, then the worker is obliged to use masks at work. Furniture industry owners can install exhaust equipped with a bag filter so that the dust that comes out can be joined first so as not to pollute the environment, equip the machinery in the furniture industry with a special cover and equipped with Place of dust, and the owner can put a no-smoking poster in the work area of furniture industry.

\section{REFERENCE}

Amelia, N. G.S., Oksfriani, J.S., H.B., 2016. Kapasitas Vital Paru Pekerja Mebel di Kelurahan Kampung Islam Manado. Jurnal Kesehatan Universitas Sam Ratulangi Manado, 8(3), pp.1-6.

Anes, N, I., Kawatu PAT, dan U.J., 2015. Faktor-faktor yang Berhubungan dengan Gangguan Fungsi Paru Pada Pekerja di PT. Tonasa Line Kota Bitung. Jurnal Kesehatan Masyarakat Universitas Sam Ratulangi Manado, 5(3), pp.600607.

Budiono, I., 2007. Faktor Risiko Gangguan Fungsi Paru Pada Pekerja Pengecatan Mobil. Tesis. Universitas Diponegoro. Semarang. Departemen of Health. 2003. Modul Pelatihan Bagi Fasilitator Tenaga Kesehatan Kerja. Jakarta: Menteri Kesehatan Republik Indonesia.

Irjayanti, A., N.\& S.A., 2012. Hubungan Kadar Debu Terhirup (Respirable) dengan Kapasitas Vital Paksa Paru pada Pekerja Mebel Kayu di Kota Jayapura. Jurnal Kesehatan Lingkungan Indonesia, 11(2), pp.182-186.

Isnaini, A., Setyoko, R.B., 2015. Hubungan Masa Paparan Debu dan Kebiasaan 
Merokok dengan Fungsi Paru Pada Pekerja Mebel Antik Lho di Jepara. Jurnal Kedokteran Muhammadiyah., 2(1), pp.16-19.

Karim, F., 2006. Panduan Kesehatan Olahraga Bagi Petugas Kesehatan. Jakarta: Departemen Kesehatan.

Khumaidah, 2009. Analisis Faktor-faktor yang Berhubungan dengan Gangguan Fungsi Paru Pada Pekerja Mebel PT Kota Jati Furnindo Desa Suwawal Kecamatan Mlonggo Kabupaten Jepara. Tesis. Universitas Diponegoro. Semarang.

Ma'rufi, I., 2016. Efek Pajanan Debu Kayu Terhadap Gangguan Faal Paru. Jurnal Media Pharmaceutica Indonesiana, 1(1), pp.45-52. https://doi.org/10.24123/mpi.v1i1.5 3

Mirza, S., 2010. Risks to The Health of Wood Workers: What Can Be Done. Zagazig Journal of Occupational Health and Safety, 3(1), pp.1-8.https://doi: 10.4314/zjohs.v3i.57945

Nurkhaleda, B., S.J. dan S., 2016. Faktorfaktor yang Berhubungan dengan Kapasitas Fungsi Paru Pada Pekerja Pengelasan di PT. X Kota Semarang Tahun 2016. Jurnal Kesehatan Masyarakat, 4(3), pp.313-322.

Oviera, A., Siswi Jayanti, dan S., 2016. Faktor-faktor yang Berhubungan dengan Kapasitas Vital Paru Pada Pekerja Industri Pengolahan Kayu di PT. X Jepara. Jurnal Kesehatan Masyarakat, 4(1), pp.267-276. https://doi.org/10.22216/jen.v1i2.9 85

Permatasari, L. O., M.R. dan T.J., 2017. Hubungan Antara Kadar Debu Total dan Personal Hygiene dengan gangguan Fungsi Paru Pada Pekerja Pengolahan Kayu di CV Indo Jati Utama Semarang. Jurnal Kesehatan Masyarakat, 5(5), pp.717-723.

Pradesi, R, A.S. dan S.J., 2018. Analisis Hubungan Paparan Debu Semen dengan Kapasitas Vital Paru Pada Pekerja Departemen Produksi di PT. X Jawa Tengah. Jurnal Kesehatan Masyarakat, 6(2), pp.103 - 112 .

Purba, E.Y., 2013. Gambaran Paparan Debu dan Fungsi Paru Pada Pekerja Pembuatan Perabot Rumah Tangga di CV Kochi Sohor Terjun Medan Marelan. Skripsi. Universitas Sumatera Utara. Medan.

Rasyid, A.H., 2013. Faktor-faktor yang Berhubungan dengan Kapasitas Vital Paru Pada Pekerja di Industri Percetakan Mega Mall Ciputan Tahun 2013. Skripsi. Universitas Islam Negeri Syarif Hidayatullah. Jakarta.

Simanjuntak, N.S.R., Ari, S., Ida, W., 2013. Hubungan Antara Kadar Debu Batubara Total dan Terhirup Serta Karakteristik Individu dengan Gangguan Fungsi Paru Pada Pekerja di Lokasi Coal Yard PLTU $\mathrm{X}$ Jepara. Jurnal Kesehatan Masyarakat, 2(2), pp.1-15.

Soeripto, M., 2008. Higiene Industri. Jakarta: .: Balai Penerbit Fakultas Kedokteran Universitas Indonesia.

Sukawati, E dan Setiani, O., 2014. Kajian Gangguan Fungsi Paru Pada Pekerja Pengelasan di Kecamatan Mertoyudan Kabupaten Magelang. Jurnal Kesehatan Lingkungan Indonesia, 13(2), pp.45-50.

Suma'mur., 2009. Higiene Perusahaan dan Kesehatan Kerja (Hiperkes). Jakarta: CV Sagung Seto.

Suryono, J., 2001. Deteksi Dini Penyakit Akibat Kerja. Jakarta: CV Haji Masagung.

Yuwono, 2005. Survai Hubungan Kebiasaan Merokok dengan Kapasitas Vital Paru pada Mahasiswa Pendidikan Jasmani Kesehatan dan Rekreasi. Skripsi. Universita Negeri Surabaya. Surabaya. 